\title{
Peranan Zakat Sebagai Manifestasi Ketaqwaan Dalam Penanggulangan Kemiskinan \\ (Studi Implementasi Lembaga Amil Zakat Al-Ittihad Desa Sidowungu Kecamatan Menganti Kabupaten Gresik)
}

\author{
Lukman Abiyoso ${ }^{1}$, Darsono Wisadirana², Solih $\mathrm{Mu}^{\prime} \mathrm{adi}^{3}$ \\ ${ }^{1}$ Magister Sosiologi, Fakultas IImu Sosial dan Politik, Universitas Brawijaya \\ ${ }^{2.3}$ Fakultas IImu Sosial dan Politik, Universitas Brawijaya
}

\begin{abstract}
Abstrak
Membayar zakat adalah salah satu bentuk manifestasi ketaqwaan seseorang, dimana taqwa merupakan kunci dari pintu kesejahteraan. Sehingga ketika kita mengkaji penanggulangan kemiskinan tidak dapat dipisahkan dari ketaqwaan. Penelitian ini bertujuan untuk menganalisis (1) Pengelolaan zakat, infaq dan shodaqoh oleh Lembaga Amil Zakat AlIttihad, (2) Sasaran yang dicapai oleh Lembaga Amil Zakat Al-Ittihad dalam menanggulangi kemiskinan (pemenuhan kebutuhan dasar), dan (3) Faktor-faktor yang mengindikasikan ketaqwaan masyarakat dalam menanggulangi kemiskinan. Penelitian dilakukan di desa Sidowungu Kecamatan menganti Kabupaten Gresik dengan studi implementasi pada Lembaga Amil Zakat Al-Ittihad. Informan dari penelitian ini adalah amil, muzakki dan mustahiq yang dipilih dengan menggunakan teknik snawball sampling, dimana data yang terkumpul akan dianalisa menggunakan model interaktif (miles dan huberman,1992). Hasil dari penelitian yaitu (1) Lembaga Amil Zakat Al-Ittihad melibatkan masyarakat untuk aktif dalam pengelolaan zakat, infaq dan shodaqoh, mulai dalam perencanaan, pengumpulan, pendistribusian, sampai pada pengidentifikasian fakir miskin, (2) Lembaga Amil Zakat Al-Ittihad menggunakan dua variabel dalam mengukur kemiskinan, yaitu variabel ekonomi dan varibel non-ekonomi untuk menentukan fakir dan miskin sebagai sasaran dalam penanggulangan kemiskinan, (3) Janji ALLAH SWT dalam Al-Qur'an Surat Ath-Thalaaq ayat dua sampai ayat tiga bagi orang yang bertaqwa memotifasi masyarakat desa Sidowungu untuk bersedekah sebagai perwujudan dari ketaqwaannya.
\end{abstract}

Kata kunci : Lembaga Amil Zakat, Zakat, Taqwa, Kesejahteraan, Kemiskinan

Abstract

Paying zakat is one of taqwa manifestation, which is the key of the human welfare, so when we study about the poverty handling, it can not be separated from taqwa. This research aims to analyze(1) the management of zakat, infaq and shodaqoh by the Institute of Amil Zakat Al-Ittihad, (2) the target to be achieved by the Institution of Amil Zakat AlIttihad in reducing poverty (the fulfillment of basic needs), and (3) the factors that indicate taqwa communities to handle the poverty. The location of this research was in the village of Sidowungu, district of Menganti, residence of Gresik by study implementation on the Institute of Amil Zakat Al-Ittihad. Informants of this research are the amil, muzakki and mustahiq that was selected by using the technique of snawball sampling, in which the collected data will be analyzed using an interactive model (Miles and Huberman, 1992). The results of the study are (1) Institute of Amil Zakat Al-Ittihad involve the community to be active in the management of zakat, infaq and shodaqoh, starting in the planning, collection, distribution, until the identification of the poor, (2) Institute Amil Zakat Al -Ittihad use two variables to measure poverty, the economic variables and non-economic variables to determine the indigent and the poor as targets in handling poverty, (3) the promise of Allah SWT in the Quran Surat Ath-Thalaaq paragraph two to three paragraphs for the people whose taqwa, motivate the sidowungu villagers to charity as the embodiment of their taqwa.

Keywords: Institute Amil Zakat, Zakat, Taqwa, Welfare, proverty

Alamat Korespondensi Penulis :

Lukman Abiyoso

Email : Abifaciros@gmail.com

Alamat : Badan Kepegawaian Daerah provinsi Jawa Timur,

Jl. Jemur Andayani 1 Surabaya (60236) 


\section{PENDAHULUAN}

Kemiskinan termasuk salah satu konsep yang tidak pernah berhenti untuk diperbincangkan. Penyebab dan penanggulangannya terus dibahas seakan tidak ada habisnya. Beberapa definisi dan penyebab kemiskinan diungkap oleh berapa peneliti, diantaranya : (1). Suparlan (1994) dalam Astika (2010:21) mendefinisikan kemiskinan sebagai suatu keadaan kekurangan harta atau benda berharga yang diderita oleh seseorang atau sekelompok orang[1]; (2). Ala (1981) menjelaskan bahwa kemiskinan bersifat multidimensional yang memiliki beberapa aspek, yaitu miskin dalam hal : kekuasaan, harta benda, kesehatan, pendidikan, ketrampilan, cinta kasih, keadilan, penghargaan, keamanan, dan kebebasan[2];

Diantara wilayah Indonesia yang penduduk miskinnya relatif banyak adalah di Desa Sidowungu kecamatan Menganti Kabupaten Gresik, dimana berdasarkan data Badan Pusat Statistik pada tabel jumlah keluarga tahapan Sejahtera menurut Desa / Kelurahan di kecamatan Menganti tahun 2011, jumlah keluarga pra sejahtera di desa Sidowungu sebanyak 389 keluarga prasejahtera atau $21 \%$ dari seluruh keluarga yang ada. Artinya bahwa hampir seperempat penduduk desa Sidowungu dalam keadaan miskin.[3]

Menyadari hal tersebut maka para tokoh masyarakat desa Sidowungu kemudian membentuk Lembaga Amil Zakat Al-ittihad, yang bertujuan untuk membantu fakir miskin dan menyantuni anak yatim.

Keberadaan Lembaga Amil Zakat di Indonesia diatur dalam Undang-undang Nomor 38 Tahun 1999 tentang pengelolaan zakat yang kemudian disempurnakan dengan ditetapkannya Undang-undang No. 23 tahun 2011 tentang Pengelolaan Zakat. Hasil akhir dari pengelolaan zakat adalah kesejahteraan masyarakat dan penanggulangan kemiskinan, sehingga Lembaga Amil Zakat dituntut untuk mampu mengelola zakat secara efektif dan efisien.

Tujuan dari penelitian ini adalah : (a) Untuk menganalisis pengelolaan zakat, infaq dan shodaqoh oleh Lembaga Amil Zakat Al-Ittihad; (b) Untuk menganalisis sasaran yang dicapai oleh Lembaga Amil Zakat Al-Ittihad dalam menanggulangi kemiskinan (pemenuhan kebutuhan dasar); (c) Untuk menganalisis faktorfaktor yang mengindikasikan ketaqwaan masyarakat dalam menanggulangi kemiskinan.

\section{METODE PENELITIAN}

Metode penelitian ini menggunakan pendekatan kualitatif dengan jenis penelitian deskriptif analisis untuk memberi gambaran tentang Lembaga Amil Zakat Al-Ittihad dalam mengelola dana zakat serta kearifan lokal masyarakat dalam menanggulangi kemiskinan sebagai manifestasi ketaqwaan.

\section{Metode Pengumpulan Data}

Dalam mengumpulkan data, teknik yang digunakan adalah dengan melakukan wawancara terhadap informan menggunakan teknik snowball sampling dimana pada penelitian ini peneliti memilih informan awal dari pengurus Lembaga Amil Zakat Al-Ittihad dan dilanjutkan dengan menentukan informan berikutnya sampai akhirnya data yang diperlukan dalam penelitian ini tercapai secara maksimal. Selain melakukan wawancara, teknik yang dilakukan dalam pengumpulan data adalah dengan observasi atau pengamatan langsung ke lokasi penelitian, serta pengumpulan dokumen yang terkait dengan pengelolaan zakat.[4]

\section{Metode Analisis Data}

Peneliti menggunakan model interaktif (miles dan huberman,1992) untuk melakukan analisa data karena kegiatan pengumpulan data dan analisis data berlangsung secara simultan atau berlangsung serempak yang bersifat interaktif[5]. Soenyono (2007) menjelaskan teknik analisis data interektif yang dikemukakan oleh Miles dan Huberman (1992) yang mencakup tiga kegiatan bersamaan yaitu : (1) Reduksi data; (2) Penyajian data; (3) Menarik kesimpulan / Verifikasi.[6]

\section{HASIL DAN PEMBAHASAN}

Kemiskinan dan penanggulangannya tidak hanya menjadi tanggung jawab pemerintah saja, tetapi juga tanggung jawab masyarakat. Peran masyarakat sangat dibutuhkan untuk mendukung program pemerintah dalam penanggulangan kemiskinan. Yang dimaksud dengan masyarakat disini tidak hanya masyarakat yang sejahtera saja tetapi juga masyarakat miskin itu sendiri, sebagaimana disebutkan dalam pasal 4 UndangUndang No.13 tahun 2011 tentang penanganan fakir miskin, bahwa fakir miskin bertanggung jawab untuk : (a). Menjaga diri dan keluarganya dari perbuatan yang dapat merusak kesehatan, kehidupan sosial, dan ekonominya; (b). Meningkatkan kepedulian dan ketahanan sosial dalam bermasyarakat; (c). Memberdayakan dirinya agar mandiri dan meningkatkan taraf kesejahteraan serta berpartisipasi dalam upaya 
penanganan kemiskinan; dan (d). Berusaha dan bekerja sesuai dengan kemampuan bagi yang mempunyai potensi.[7]

Masyarakat juga memikul tanggung jawab sosial terkait keberadaan dirinya terhadap lingkungan sekitar, sebagaimana hadist Rosululloh Muhammad SAW, yang artinya "Tidaklah beriman kepada-Ku, siapa saja yang tidur kekenyangan, sedangkan tetangganya kelaparan, sementara dia mengetahuinya." [HR. Imam Bukhori, Imam Thabrani, Imam Al-hakim, Imam Baihaqi]. ${ }^{1}[8]$

Pengelolaan zakat yang baik merupakan salah satu cara dalam penanggulangan kemiskinan, hal ini dibuktikan oleh Irfan Syauqi Beik dalam penelitiannya yang berjudul "Analisis Peran Zakat dalam Mengurangi kemiskinan : Studi kasus Dompet Duafa Republika". Dari hasil penelitiannya beik (2009), menyatakan bahwa zakat mampu mengurangi jumlah keluarga miskin dari 84 persen menjadi 74 persen. [9]

Lembaga Amil Zakat Al-Ittihad merupakan Lembaga Amil Zakat tingkat desa yang didirikan sekitar tahun 2004 sebagai upaya untuk memudahkan masyarakat dalam mengumpulkan dan mendistribusikan zakat, Infaq dan shodaqoh sekaligus untuk mengkoordinasikan penanggulangan kemiskinan agar lebih dapat dirasakan manfaatnya bagi masyarakat miskin di Desa Sidowungu, Kecamatan Menganti, Kabupaten Gresik.

\section{Pengelolaan Zakat, Infaq dan Shodaqoh}

Dalam menganalisis pengelolaan zakat, infaq dan shodaqoh, pada Lembaga Amil Zakat Alittihad dilakukan melalui dua pendekatan, yaitu : definisi dan tujuan penegelolaan zakat, infaq dan shodaqoh.

Definisi pengelolaan zakat sebagaimana tertuang dalam pasal 1 ayat (1) Undang-undang No. 38 tahun 1999 tentang pengelolaan zakat, adalah kegiatan yang meliputi [10]:

(1) Perencanaan

Dalam hal pengelolaan zakat, infaq dan shodaqoh Lembaga Amil Zakat Al-Ittihad selalu merencanakan kegiatan yang akan dilakukan dengan cara melakukan pertemuan amil zakat. Pertemuan yang sifatnya rutin dilakukan pada :

(a) Awal bulan ramadhan, membahas tentang kondisi terakhir masyarakat.

\footnotetext{
${ }^{1}$ Hadist diterjemahkan dari kitab Al Jamius Shoghir Fil Ahadisil Basyirin Nadhir juz II halaman 135 karya Imam Jalaludin AsSuyuthi cetakan Darul Fikr Beirut
}

(b) Pertengahan bulan Ramadhan, membahas tentang daftar nama fakir dan miskin tiaptiap RT.

(c) Akhir bulan Ramadhan, membahas tentang perolehan zakat fitrah, distribusi zakat fitrah, distribusi santunan hari raya, serta pembagian kepada fakir dan miskin Selain pertemuan rutin, Lembaga Amil Zakat Al-Ittihad juga melakukan pertemuan tidak rutin yang sifatnya insidentil.

(2) Pengorganisasian

Sebagai sebuah organisasisi, Lembaga Amil Zakat Al-ittihad juga mempunyai pengurus yang disebut amil, untuk menjalankan rencana kegiatan-kegiatan atau program kerja yang sudah disepakati. Para amil terdiri dari tokoh agama, tokoh masyarakat dan warga.

(3) Pelaksanaan

Lembaga Amil Zakat Al-Ittihad membagi kegiatan pengumpulan dan distribusi zakat, infaq dan shodaqoh dalam dua waktu, yaitu

(a) khusus bulan ramadhan, kegiatan yang dilakukan adalah pengumpulan dan distribusi zakat fitrah, pengumpulan zakat maal, distribusi santunan hari raya. $\mathrm{Hal}$ ini dimaksudkan agar fakir, miskin dan anak yatim dapat merasakan kebahagiaan pada saat hari raya idul fitri

(b) Setiap bulan dalam satu tahun, kegiatan yang dilakukan adalah pengumpulan Infaq dan shodaqoh dari warga (setiap tanggal 25 sampai 27 setiap bulannya), distribusi infaq dan shodaqoh untuk santunan pendidikan anak yatim, insentif Taman pendidikan Alqur'an, santunan obat fakir miskin, serta santuna anak yatim dengan permintaan khusus dari donatur.

(4) Pengawasan

Pengawasan dalam pelaksanaan organisasi dilakukan oleh takmir masjid dan warga masyarakat dengan membaca laporan keuangan yang dibagikan satu tahun sekali pada pertemuan amil di bulan ramadhan.

Tujuan Pengelolaan Zakat sebagaimana diatur dalam pasal 3 Undang-Undang No. 23 tahun 2011 tentang Pengelolaan Zakat adalah meningkatkan efektivitas dan efisiensi dalam pengelolaan zakat serta meningkatkan manfaat zakat dengan mewujudkan kesejahteraan dan penanggulangan kemiskinan[11]. Kata kunci dari pasal 3 Undang-Undang tersebut adalah efektifitas, efisiensi, mewujudkan kesejahteraan dan penanggulangan kemiskinan.

Ada tiga program pokok yang dilakukan oleh Lembaga Amil Zakat Al-Ittihad, yaitu : 
(1) Pengelolaan Zakat Fitrah

Pada umumnya pengumpulan dan pendistribusian beras zakat fitrah dilakukan di masjid atau musholah, tetapi hal berbeda dilakukan oleh Lembaga Amil Zakat Al-Ittihad, yaitu dengan memfungsikan ketua RT menjadi amil zakat yang bertugas mengumpulkan dan mendistribusikan beras zakat fitrah. Beras yang terkumpul di salah satu RT tidak hanya didistribusikan untuk warganya saja melainkan juga untuk warga di RT lain yang kekurangan, sebagai contoh pada RT 17 berhasil mengumpulkan beras sebanyak 147 kantong beras, dan hanya 84 kantong saja yang didistribusikan untuk warganya, sedangkan sisanya didistribusikan untuk RT lain yang kekurangan. Dan setiap fakir miskin dimasingmasing RT memperoleh beras dengan jumlah yang sama yaitu 16 kantong atau sekitar 40 kilogram untuk yang fakir, sedangkan yang miskin mendapat 9 kantong beras atau sekitar 22,5 kilogram, sebagaimana dapat dilihat dalam tabel berikut :

Tabel 1. Rekap zakat fitrah tahun 2014

\begin{tabular}{|c|r|r|r|r|r|}
\hline \multirow{2}{*}{ RT } & \multirow{2}{*}{$\begin{array}{r}\text { PENERI } \\
\text { MAAN }\end{array}$} & \multicolumn{3}{|c|}{ PEMBAGIAN } & $\begin{array}{c}\text { TOTAL } \\
\text { PEMBA } \\
\text { GIAN }\end{array}$ \\
\cline { 3 - 5 } & & FAKIR & MISKIN & AMIL & \multicolumn{1}{|c|}{} \\
\hline 17 & 147 & 0 & 72 & 12 & 84 \\
\hline 18 & 220 & 32 & 162 & 12 & 206 \\
\hline 19 & 165 & 48 & 153 & 12 & 213 \\
\hline 20 & 199 & 128 & 99 & 12 & 239 \\
\hline 21 & 160 & 32 & 90 & 12 & 134 \\
\hline 22 & 143 & 96 & 81 & 12 & 189 \\
\hline 23 & 110 & 16 & 90 & 12 & 118 \\
\hline 24 & 180 & 96 & 63 & 12 & 171 \\
\hline 25 & 79 & 0 & 27 & 8 & 35 \\
\hline Total & 1403 & 448 & 837 & 104 & 1389 \\
\hline
\end{tabular}

catatan:

Fakir menerima 16 kantong

Miskin

menerima 9 kantong

Amil Menerima 4 kantong

Sisa 14 kantong digunakan untuk biaya operasional

Sumber: laporan penerimaan dan penyaluran zakat fitrah

Lembaga Amil Zakat Al-ittihad telah berhasil meningkatkan efektifitas dengan meningkatnya jumlah beras yang terkumpul yaitu sebanyak 1.336 kantong pada tahun 2013 menjadi 1.403 kantong pada tahun 2014, sehingga dapat meningkatkan pula jumlah beras yang diterima fakir miskin, menjadi masing-masing fakir mendapat 13 kantong pada tahun 2013 dan 16 kantong pada tahun 2014.

Hal positif dari dilibatkannya ketua RT dalam pengumpulan dan distribusi zakat fitrah adalah : (a). Hemat, yaitu Lembaga Amil Zakat tidak perlu menugaskan orang (Amil) di masjid dari pagi sampai malam hanya untuk menerima beras zakat Fitrah; (b). Mendekatkan nilai-nilai keagamaan yang bersifat sosial dengan masyarakat, karena ketua RT juga melibatkan warganya dalam pengumpulan dan distribusi beras zakat fitrah. (c). Membangun solidaritas sosial antar masyarakat dengan cara membagi beras zakat fitrah dengan RT yang kekurangan.

(2) Pengelolaan Zakat Maal

Lembaga Amil Zakat Al-Ittihad mengumpulkan zakat maal pada bulan suci ramadhan, cara pengumpulan zakat maal dilakukan dengan memberikan surat pemberitahuan kepada muzakki tentang pengumpulan zakat maal, dan biasanya satu minggu setelah surat diterima muzakki, ada petugas (amil) yang mengambil di rumah masing-masing muzakki. Pada pengumpulan zakat maal ini amil zakat telah berhasil meningkatkan efektifitas dengan meningkatnya jumlah zakat yang yang terkumpul dan meningkatnya jumlah penerimaan santunan hari raya maupun santunan bulanan bagi fakir miskin, yaitu seperti tergambar pada tabel berikut :

Tabel 2. Rekap santunan hari raya dan santunan bulanan (angka dalam ribuan)

\begin{tabular}{|c|c|c|c|c|c|c|c|c|c|c|c|}
\hline \multirow[b]{2}{*}{ No } & \multirow[b]{2}{*}{ ahun } & \multicolumn{3}{|c|}{$\begin{array}{l}\text { Santunan Hari } \\
\text { Raya Fakir }\end{array}$} & \multicolumn{3}{|c|}{$\begin{array}{c}\text { Santunan Bulanan } \\
\text { Fakir }\end{array}$} & \multicolumn{3}{|c|}{$\begin{array}{c}\text { Santunan Hari } \\
\text { Raya Miskin }\end{array}$} & \multirow{2}{*}{\begin{tabular}{|c} 
Jumlah \\
Penerim \\
aan \\
Zakat \\
maal \\
(Rp)
\end{tabular}} \\
\hline & & Jml & $\mathrm{Rp}$ & $\begin{array}{c}\text { Total } \\
\mathrm{Rp}\end{array}$ & $\mathrm{Jml}$ & $\mathrm{Rp}$ & Total $\mathrm{Rp}$ & Jml & $\mathrm{Rp}$ & $\begin{array}{c}\text { Total } \\
\mathrm{Rp}\end{array}$ & \\
\hline 1 & 2007 & 39 & 60 & 2.340 & 18 & 35 & .560 & 67 & 15 & 1.00 & 13.547 \\
\hline 2 & 08 & 34 & 60 & 0 & 18 & 35 & 0 & 81 & 5 & 2.025 & 12 \\
\hline 3 & 09 & 33 & 75 & 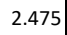 & $\mid$ & 50 & 200 & 83 & 170 & 3.3 & 19.114 \\
\hline 4 & 2010 & 32 & 75 & 2.400 & 17 & 50 & 0.200 & 81 & 40 & 3.24 & 19.795 \\
\hline 5 & 2011 & 32 & 80 & 2.560 & 17 & 50 & .200 & 78 & 45 & 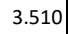 & 16.6 \\
\hline 6 & 2012 & 291 & 100 & 2.900 & 17 & 50 & 10.200 & 89 & 70 & 6.230 & 19.669 \\
\hline 7 & 2013 & 30 & 100 & 3.000 & 30 & 30 & 10.800 & 92 & 70 & 6.440 & 22.660 \\
\hline 8 & 14 & 28 & 100 & 800 & 28 & 35 & .760 & 93 & 75 & 5.97 & 22.5 \\
\hline
\end{tabular}

Sumber: laporan penerimaan dan penyaluran zakat maal

Dari tabel 2 dapat diketahui bahwa jumlah santunan untuk fakir miskin meningkat dari tahun sebelumnya. Peningkatan jumlah santunan yang diterima oleh fakir miskin sedikit banyak dapat meningkatkan kesejahteraan fakir miskin. Santunan hari raya bertujuan agar fakir miskin dapat merasakan kebahagiaan pada saat hari raya idul fitri, sedangkan santunan bulanan bertujuan untuk sedikit mensejahterakan fakir dalam kehidupan sehari-hari, yang dapat digunakan untuk membayar listrik atau menambah gizi keluarga.

(3) Pengelolaan Infaq dan Shodaqoh 
Lembaga Amil Zakat Al-ittihad mengumpulkan infaq dan shodaqoh dari para donatur pada setiap tanggal 25 sampai tanggal 27 setiap bulannya. Para donatur terdiri dari pelbagai kalangan mulai yang berpenghasilan tingi maupun rendah. Amil zakat telah berhasil meningkatkan efektifitas dan efisiensi, hal ini ditandai dengan meningkatnya jumlah infaq dan shodaqoh yang terkumpul, yaitu sebesar Rp. 21.799.500 pada tahun 2011, Rp. 24.112.500, pada tahun 2012, Rp. 36.241 .000 pada tahun 2013 dan Rp. 41.527.500 pada tahun 2014, serta meningkatnya target pendidikan bagi anak yatim yang semula setingkat Sekolah Menengah Pertama menjadi setingkat Sekolah Menengah Atas dan mulai tahun 2014 anak yatim yang sekolah akan mendapat uang saku.

Pendistribusian Infaq diprioritaskan untuk memberi santunan kepada anak yatim dalam bentuk biaya pendidikan, santunan hari raya dan santunan khusus sesuai permintaan donatur, kemudian selebihnya untuk memberi santunan kepada fakir dan miskin yang sakit, modal usaha, sampai pada perbaikan rumah fakir dan miskin yang sudah tidak layak huni.

Biaya pendidikan anak yatim dimaksudkan sebagai ikhtiar untuk memberi bekal ilmu kepada anak yatim agar dikemudian hari mendapat pekerjaan yang layak. Hal ini sesuai dengan rekomendasi corak (2006) dalam makalah yang berjudul "Do poor children become poor adults" yang merekomendasikan kepada pemerintah agar melakukan investasi pendidikan bagi anakanak untuk memastikan bahwa anak-anak tersebut memiliki keterampilan dan pendidikan yang tinggi agar membuka peluang untuk mendapat penghasilan yang tinggi, karena pendapatan yang lebih tinggi akan diperoleh bagi Individu terampil atau Individu berpendidikan lebih tinggi. [12]

Dari pembahasan yang menggunakan dua pendekatan sebagaimana diuraikan di atas, dapat dikatakan bahwa Lembaga Amil Zakat Al-ittihad mampu mengelolah zakat dengan baik. Dampak dari pengelolaan zakat yang baik adalah terwujudnya kesejahteraan masyarakat dan menumbuhkan kepercayaan dari muzakki dan donatur untuk menyalurkan zakat, infaq dan shodaqoh melalui Lembaga amil zakat Al-Ittihad.

\section{Sasaran yang dicapai}

Untuk menentukan penduduk miskin diperlukan kriteria sebagai alat bantu mengidentifikasi penduduk miskin. Ada beberapa kriteria yang sudah umum digunakan, diantaranya adalah yang digunakan oleh Badan Pusat Statistik dan yang digunakan oleh Badan Koordinasi Keluarga Berencana Nasional (BKKBN). Dari hasil penelitian dapat diketahui bahwa Lembaga Amil Zakat Al-Ittihad membagi tingkat keparahan kemiskinan menjadi dua, yaitu : Fakir dan Miskin. Walaupun sama-sama miskin tetapi penduduk yang fakir adalah yang lebih miskin dari penduduk miskin. Didalam menentukan penduduk yang termasuk fakir dan yang termasuk miskin, Lembaga Amil Zakat AlIttihad menyerahkan sepenuhnya kepada ketua RT, hal ini didasari pada pemikiran bahwa ketua RT adalah orang yang secara struktural paling dekat dengan masyarakat, sehingga diharapkan mampu mengidentifikasi penduduknya yang fakir maupun yang miskin.

Lembaga Amil Zakat Al-Ittihad tidak hanya mengukur kemiskinan dari variabel ekonomi saja yang mengukur kemiskinan menurut batas "garis kemiskinan" tetapi juga dari variabel nonekonomi, seperti status perkawinan, status pekerjaan, kesehatan, dan kondisi anak atau saudaranya, seperti pada tabel berikut :

Tabel 3. Faktor dan Kondisi Indikator fakir miskin²

\begin{tabular}{|l|l|l|}
\hline No & \multicolumn{1}{|c|}{ Faktor } & \multicolumn{1}{|c|}{ Kondisi } \\
\hline 1 & Usia & Lebih dari 50 tahun \\
\hline 2 & Kesehatan & $\begin{array}{l}\text { Sering sakit (sehingga } \\
\text { kemampuan bekerjanya } \\
\text { menurun atau tidak bisa } \\
\text { bekerja sama sekali) }\end{array}$ \\
\hline 3 & Pekerjaan & $\begin{array}{l}\text { Pekerja kasar dan tidak tetap } \\
\text { (buruh tani, kuli batu, dII), } \\
\text { menjahit majun (kain perca), } \\
\text { pembantu riumah tangga, dan } \\
\text { tidak bekerja }\end{array}$ \\
\hline 4 & Status perkawinan & $\begin{array}{l}\text { Janda } \\
\text { Masih sekolah, tidak bekerja, } \\
\text { pekerja kasar dengan } \\
\text { tanggungan keluarga, cacat }\end{array}$ \\
\hline
\end{tabular}

Kelebihan dari cara ini adalah data yang dihasilkan lebih lengkap dan realistis karena ketua RT (selaku amil) melakukan pengamatan dengan menggunakan faktor dan kodisi yang ada (sesuai tabel 3 diatas) yang kemudian dianalisa apakah masuk dalam kelompok fakir atau miskin. Cara ini disebut oleh Maika (2009) sebagai pengukuran kemiskinan subyektif. Maika (2009) dalam Hermawati (2013:6) mengemukakan, bahwa indikator ekonomi bukan satu-satunya metode untuk mengukur kemiskinan.[13]

Dari hasil penelitian dapat diketahui bahwa secara umum yang termasuk dalam fakir atau miskin adalah janda yang tidak bekerja atau

\footnotetext{
${ }^{2}$ Disarikan darimhasil wawancara dengan ketua RT
} 
janda yang penghasilannya sangat sedikit ditambah beban tanggungan keluarga serta orang yang produktifitasnya mulai menurun karena sering sakit atau yang tidak dapat bekerja karena sakit permanen (biasanya dialami pada orang tua lanjut usia). Para janda tersebut langsung masuk ke dalam daftar fakir atau miskin ketika suaminya meninggal dunia / cerai disebabkan oleh beberapa faktor, diantaranya adalah : (a) Tidak memiliki tabungan yang cukup karena suami berpenghasilan rendah; (b) Tingkat pendidikan rendah; (c) Tidak memiliki keterampilan; (d) Memiliki tanggungan keluarga (anak yang masih sekolah). Sedangkan para orang tua lanjut usia yang masuk dalam daftar fakir miskin, disebabkan oleh kondisi fisik mereka yang tidak kuat lagi untuk bekerja. Hal ini karena profesi mereka adalah pekerja kasar yang berpenghasilan rendah, sehingga tidak memiliki tabungan untuk hari tua. Sedangkan anak-anak mereka umumnya juga berprofesi sebagai pekerja kasar yang hanya cukup untuk menghidupi istri dan anaknya saja sehingga tidak dapat banyak membantu orang tuanya. Dari kondisi tersebut dapat dikatakan bahwa masyarakat terjebak dalam suatu perangkap kemiskinan yang terus berulang dari satu generasi ke generasi berikutnya sehingga membentuk suatu siklus kemiskinan, seperti yang tergambar pada skema berikut :

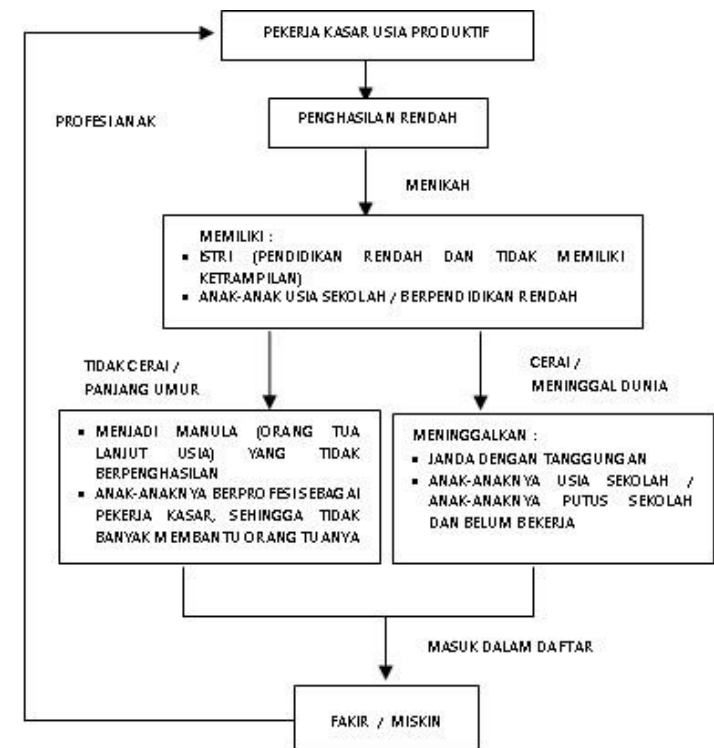

Gambar 1. Skema siklus kemiskinan di desa Sidowungu (diolah dari hasil penelitian)

Apa yang tergambar dari skema siklus kemiskinan diatas adalah suatu kondisi masyarakat yang terjebak dalam keadaan dimana mereka sangat rentan untuk masuk ke dalam daftar fakir miskin. Kerentanan itu disebabkan oleh beberapa faktor, diantaranya adalah :

(a) Penghasilan rendah.

Penghasilan yang rendah membuat seorang kepala keluarga kesulitan untuk memenuhi kebutuhan dasar bagi keluarganya, yang dapat mengakibatkan rendahnya kualitas hidup anggota keluarga yang mana dalam jangka panjang berdampak pada rendahnya daya saing.

(b) Pendidikan rendah

Keterbatasan dalam memperoleh pendidikan formal maupun non-formal bagi anak-anak salah satunya dipengaruhi oleh rendahnya penghasilan dari kepala keluarga. Kesempatan kerja yang dimiliki oleh mereka yang berpendidikan rendah adalah pada pada sektor non-formal yang tidak membutuhkan keterampilan yang tinggi, misalnya menjahit majun, buruh tani, buruh bangunan dan buruh pada usaha rumah tangga. Beberapa jenis pekerjaan tersebut hanya menghasilkan upah yang rendah (biasanya dibawah upah minimum kabupaten / kota)

(c) Kelemahan fisik

kelemahan fisik diantaranya disebabkan oleh usia, asupan gizi, kebersihan lingkungan, cacat, dan perawatan kesehatan yang kurang baik serta terlalu gigihnya dalam bekerja tanpa memperhitungkan keseimbangan tenaga yang dikeluarkan dengan masa istirahat dan makanan yang dikonsumsi. Kelemahan fisik dapat mengurangi peluang seseorang bekerja pada sektor formal. Dengan fisik yang lemah produktifitas seseorang dapat menurun bahkan sampai pada titik tidak berproduksi sama sekali.

Beberapa faktor itulah yang disebut dengan perangkap kemiskinan yang unsur-unsurnya terhubung satu dengan yang lain sehingga oleh Chambers (1987) digambarkan dalam suatu jebakan penjarahan (deprivation).[14]

Faktor lain yang merupakan awal dari kemiskinan di pedesaan adalah pertumbuhan penduduk yang tidak terkendali sehingga mengakibatkan : kepemilikian seseorang akan tanah pertanian semakin sempit (sebagai akibat dari sepetak tanah yang terbagi-bagi kepada ahli warisnya) serta menurunnya hasil (pendapatan) dari sektor pertanian karena hasil panen harus dibagi dengan banyaknya pekerja yang mengandalkan tanah pertanian. Hal ini dijelaskan oleh Geertz (1976) sebagai kemiskinan yang dibagi rata. Akibat lain dari pertumbuhan 
penduduk yang tidak terkendali adalah : kebutuhan akan rumah tinggal yang semakin tinggi serta alih fungsi tanah pertanian menjadi jalan, Industri, dan pergudangan mengakibatkan semakin sempitnya tanah pertanian.[15]

Siklus kemiskinan menunjukkan bahwa anak-anak yang dilahirkan dalam kemiskinan cenderung untuk tetap dalam kemiskinan karena minimnya kemampuan untuk pergi ke sekolah atau mendapat pendidikan non-formal yang memadai, serta pendapatan yang rendah dari kepala keluarga membuat kondisi keuangan keluarga yang tidak stabil.

Corak (2006) pada makalah yang berjudul "Do poor children become poor adults" menjelaskan bahwa di Amerika Serikat hampir setengah dari anak yang lahir dari orang tua berpenghasilan rendah, menjadi orang dewasa yang berpenghasilan rendah juga. Hal ini juga terjadi pada empat dari sepuluh orang berpenghasilan rendah di Inggris dan sepertiga di Kanada. Makalah ini juga menjelaskan bahwa uang (kekayaan) bukan satu-satunya faktor paling penting yang mempengaruhi mobilitas pendapatan antar generasi. Ada faktor penting lainnya yaitu kesempatan bagi anak-anak untuk memperoleh keterampilan dan pendidikan yang lebih tinggi. [12]

Sebagai upaya untuk menghentikan siklus kemiskinan tersebut Lembaga Amil Zakat Alittihad mendesain sasaran yang dicapai dalam dua instrumen pokok yaitu : zakat (zakat fitrah dan zakat maal) serta infaq dan shodaqoh. Terdapat perbedaan dalam menentukan sasaran dan alokasi dana antara pendayagunaan zakat dan pendayagunaan infaq dan shodaqoh, yaitu :

(1) Penerima dana zakat adalah fakir miskin, yang mana dana yang didistribusikan bersifat konsumtif untuk membantu kebutuhan sehari-hari. Hal ini dikarenakan kecilnya dana zakat yang terkumpul dibanding dengan banyaknya jumlah fakir miskin.

(2) Penerima dana infaq dan shodaqoh diprioritaskan untuk menyantuni anak yatim, terutama untuk membiayai pendidikan anak yatim sampai tingkat Sekolah Menengah Atas dengan harapan dapat memperoleh pekerjaan yang layak.

Dari sasaran yang dicapai dapat dikatakan bahwa Lembaga Amil zakat Al-Ittihad sesungguhnya telah berada pada jalur yang tepat dalam menanggulangi kemiskinan sebagaimana tujuan dari pengelolaan zakat. Program penanggulangan kemiskinan yang dilakukan secara swadaya oleh masyarakat melalui lembaga Amil Zakat sesungguhnya telah menjadi pelengkap dari program penanggulangan kemiskinan yang dilakukan pemerintah. Sebagai contoh : beras yang diterima dari program beras miskin, jika dimasak menjadi nasi, akan lebih nikmat dan bergizi jika dimakan dengan lauk yang dibeli dari uang zakat. Contoh lain adalah terkait dengan biaya pendidikan. Anak-anak yatim tidak akan dapat sekolah jika hanya mendapatkan dana BOS (biaya operasional sekolah) dari pemerintah saja, hal ini dikarenakan untuk dapat sekolah juga membutuhkan buku, tas, alat tulis, seragam sekolah, sepatu, dan biaya transportasi ke sekolah. Oleh karena itulah maka biaya pendidikan untuk anak yatim digunakan untuk keperluan sekolah secara keseluruhan, mulai dari buku, seragam sekolah, sepatu, biaya ujian, biaya praktikum dan biaya lainnya yang menunjang kegiatan belajar di sekolah.

Faktor-faktor yang mengindikasikan ketaqwaan masyarakat dalam penanggulangan kemiskinan

Kemiskinan menjadi masalah yang sangat pelik bagi seluruh negara di dunia, pelbagai upaya sudah dilakukan dengan segala keberhasilan dan kegagalannya. Jauh sebelum era manusia modern mengkaji dan mempelajari tentang pelbagai penyebab kemiskinan dan penanggulangannya, ALLAH SWT sudah memberikan petunjuk sebagai langkah awal dalam menanggulangi kemiskinan. Sebagaimana difirmankan dalam Surat Ath-Thalaaq ayat dua sampai ayat tiga yang artinya "........ barangsiapa yang bertaqwa kepada ALLAH niscaya Dia akan mengadakan baginya jalan keluar. Dan memberinya rezki dari arah yang tiada disangkasangkanya. Dan barangsiapa yang bertawakal kepada ALLAH niscaya ALLAH akan mencukupkan (keperluan)nya.....". Dari Firman ALLAH SWT tersebut dijelaskan bahwa jika kita bertaqwa kepada ALLAH SWT maka segala urusan kita akan dimudahkan oleh ALLAH SWT dan ALLAH SWT akan memberi kita rezeki dari jalan yang tidak kita duga sebelumnya. Sehingga kesejahteraan selalu bersama orang yang bertaqwa. Bertaqwa bukan berarti hanya berserah diri kepada ALLAH SWT dengan tidak melakukan upaya apapun, sebab secara umum arti Taqwa adalah menjalankan perintah ALLAH SWT dan menjauhi larangan ALLAH SWT, sehingga orang yang bertaqwa adalah orang yang senantiasa secara istiqomah menjalankan perintah ALLAH SWT dan menjauhi larangan ALLAH SWT.

Kita diperintahkan oleh ALLAH SWT untuk bekerja keras Sebagaimana firman ALLAH SWT dalam surat Al-Mulk ayat 15 , yang artinya : “ 
Dialah yang menjadikan bumi mudah bagi kamu, maka berjalanlah di segala penjurunya dan makanlah sebahagian dari rezki-Nya, dan hanya kepada-Nya-lah kamu (kembali setelah) dibangkitkan.". Tentunya dalam bekerja untuk mencari rezeki-Nya kita harus menjalankan aturan-aturan dan menjauhi larangan-larangan yang ditetapkan oleh ALLAH SWT serta menjalankan perintah ALLAH SWT lainnya yang merupakan indikasi dan sifat orang-orang yang bertaqwa. Sehingga ketika kita akan melakukan sesuatu, kita harus memikirkan terlebih dahulu apakah perbuatan yang akan kita lakukan tersebut merupakan perintah ataukah larangan ALLAH SWT. Hal tersebut kita lakukan sebagai ikhtiar agar kita termasuk orang-orang yang bertaqwa.

Dalam Al-Qur'an surat Al-Baqarah ayat dua sampai ayat empat disebutkan ciri-ciri orang yang bertaqwa, yaitu mereka yang : beriman kepada yang ghaib, mendirikan sholat, menafkahkan sebahagian rezki yang dianugerahkan oleh ALLAH SWT, beriman kepada Kitab suci yang telah diturunkan ALLAH SWT, dan yakin akan adanya (kehidupan) akhirat. Sedangkan sifat- sifat orang yang bertaqwa disebutkan dalam Al-Qur'an surat Ali 'Imran ayat 133 sampai ayat 135 yaitu mereka yang : menafkahkan (hartanya) baik diwaktu lapang maupun sempit, menahan amarahnya, mema'afkan (kesalahan) orang, dan apabila mengerjakan perbuatan keji atau menganiaya diri sendiri, mereka ingat akan Allah, lalu memohon ampun terhadap dosa-dosa mereka.

Dari ciri-ciri dan sifat orang yang bertaqwa sebagaimana disebutkan diatas khususnya pada ciri : menafkahkan sebahagian rezki yang dianugerahkan oleh ALLAH SWT serta pada sifat : menafkahkan (hartanya) baik diwaktu lapang maupun sempit adalah ciri dan sifat orang bertaqwa yang berhubungan langsung dengan judul penelitian, karena membayar zakat serta mengeluarkan infaq dan shodaqoh merupakan manifestasi dari sikap menafkahkan harta. Zakat adalah ibadah yang memiliki dimensi vertikal dan horizontal. Yang mana dengan membayar zakat dan mengeluarkan infaq dan shodaqoh berarti kita telah melakukan bentuk ketaatan kita kepada ALLAH SWT dan sekaligus membantu sesama manusia yang kekurangan.

Dari hasil penelitian dapat diketahui bahwa sesungguhnya masyarakat desa Sidowungu memiliki kesadaran yang cukup tinggi dalam menjalankan perintah ALLAH SWT untuk menafkahkan sebagian hartanya dalam bentuk zakat, infaq dan shodaqoh. Para muzakki mengatakan bahwa alasan mereka membayar zakat, infaq dan shodaqoh dikarenakan ketaatan mereka untuk melaksanakan perintah ALLAH SWT. Dari keihlasan dan ketaatan inilah, muzakki merasakan dampak positif dalam kehidupannya berupa ketentraman hati, kemudahan rejeki dan keharmonisan rumah tangga. Sehingga hal ini semakin memotifasi mereka untuk terus bersedekah.

Selain menyalurkan zakat, infaq dan shodaqohnya melalui Lembaga Amil Zakat, para muzakki juga menafkahkan sebagian hartanya langsung kepada mustahiq (karyawan, saudara dan fakir dan miskin) di sekitarnya. Hal ini dilakukan untuk menumbuhkan ikatan solidaritas sosial antara muzakki dengan mustahiq. Dengan memberikan langsung kepada mustahiq disekitarnya (tetangganya), muzakki dapat melihat langsung kondisi mustahiq sehingga dapat menumbuhkan rasa empati dan semakin menumbuhkan rasa syukur kepada ALLAH SWT.

Lembaga Amil Zakat Al-Ittihad tidak hanya mengelola zakat saja, tetapi juga Infaq dan Shodaqoh. Jika kita menganalisa data infaq yang sampai hari ini memiliki saldo Rp. 69.755.400,maka dapat diartikan bahwa sesungguhnya masyarakat desa Sidowungu memiliki kesadaran yang tinggi untuk menafkahkan sebagian rejekinya. Hal ini dikarenakan mereka yang berinfaq dan bersedekah tidak hanya orang kaya saja tetapi juga masyarakat umum yang hartanya kurang dari satu nishob, dalam arti semua kalangan di desa Sidowungu terlibat dalam penanggulangan kemiskinan melalui lembaga amil zakat.

Apa yang dilakukan para muzaki dan donatur adalah bentuk dari sikap taqwa karena sesuai dengan ciri dan sifat orang betaqwa yaitu menafkahkan sebagian hartanya baik dalam keadaan lapang maupun sempit. Dan ALLAH SWT telah membuktikan janjinya bahwa kepada siapa saja yang bertaqwa akan diberikan jalan keluar dari segala kesulitannya, dan ALLAH SWT akan memberi rejeki bagi mereka yang bertaqwa dari jalan yang tidak diduga sebelumnya.

Membayar zakat serta mengeluarkan infaq dan shodaqoh dapat dikaji dari perspektif ilmu sosial. Hal ini dikarenakan membayar zakat serta mengeluarkan infaq dan shodaqoh merupakan ibadah yang memiliki dimensi vertikal dan horisontal. Melalui ibadah ini ALLAH SWT mengajarkan kepada kita untuk saling berbagi dan memperdulikan tetangga, yang dalam ilmu sosial dapat disebut dengan pertukaran sosial dan solidaritas sosial. 
Para muzakki mengungkapkan bahwa mereka semakin termotifasi untuk terus membayar zakat serta mengeluarkan infaq dan shodaqoh karena merasakan dampak positif dalam kehidupannya berupa ketentraman hati, kemudahan rejeki dan keharmonisan rumah tangga. Selain dampak positif yang dirasakannya itu, para muzakki juga berharap do'a dari anak yatim serta fakir dan miskin karena do'a dari anak yatim serta fakir dan miskin sangat mustajabah. Dan yang paling utama dari dampak positif dan harapannya itu para muzakki mengharap ridho dari ALLAH SWT atas segala amal baiknya.

Segala hal yang dapat memotifasi para muzakki untuk terus beramal baik melalui zakat, infaq dan shodaqoh itulah yang dalam ilmu sosial pada teori pertukaran sosial yang dikenalkan oleh George Homans dapat dianalogkan dalam proposisi nilai, yaitu menyatakan bahwa makin tinggi nilai hasil tindakan seseorang bagi dirinya, makin besar kemungkinan ia melakukan tindakan itu (Salim, 2008; Ritzer dan Goodman, 2004).[16] [17]

Saat ini desa Sidowungu sudah menjadi daerah setengah kota karena posisinya yang berbatasan dengan kota surabaya. Lahan pertanian semakin sempit tergerus oleh derasnya pembangunan kota. Kondisi ini membuat warga sidowungu memiliki profesi lebih beragam yang tidak didominasi lagi oleh petani walaupun sebagian besar masih merupakan pekerja kasar. Namun demikian budaya gotong royong masih sangat tinggi hal ini dibuktikan dengan terbentuknya Lembaga Amil Zakat yang berfungsi sebagi jaring sosial di masyarakat untuk membantu masyarakat fakir, miskin dan anak yatim.

Masyarakat desa Sidowungu masih terlihat "guyub" walaupun berbeda profesi dapat disebut sebagai ketergantungan fungsional yang merupakan ciri dari tipe solidaritas organik dalam teori solidaritas Emile Durkheim. Masyarakat desa Sidowungu juga memiliki kesadaran kolektif yang kuat untuk saling berbagi dan memperhatikan keadaan tetangganya. Dengan melibatkan ketua RT dalam amil zakat menunjukkan bahwa nilai-nilai keagamaan dengan nilai-nilai sosial dalam masyarakat dapat berdampingan. Kesadaran kolektif yang kuat di desa Sidowungu ini merupakan ciri dari tipe solidaritas mekanik dalam teori solidaritas Emile Durkheim.[18]

\section{KESIMPULAN}

Pengelolaan zakat, infaq dan shodaqoh oleh Lembaga Amil Zakat Al-ittihad melalui program pembagian zakat fitrah, santunan hari raya, santunan bulanan, santunan obat, pemberdayaan ekonomi (bantuan modal usaha), dan santunan biaya pendidikan, telah sesuai yang diamanatkan dalam undang-undang No. 23 tahun 2011 tentang pengelolaan zakat yaitu mewujudkan kesejahteraan dan menanggulangi kemiskinan. Sebagai Lembaga Amil Zakat tingkat desa yang berbasis masjid, dalam mengelola zakat, infaq dan shodaqoh Lembaga Amil Zakat Al-Ittihad juga melibatkan masyarakat untuk aktif dalam pengelolaan zakat, infaq dan shodaqoh. Hal ini dapat memberi nilai positif yaitu dapat mendekatkan nilai-nilai keagamaan yang bersifat sosial dengan masyarakat dan membangun solidaritas sosial antar masyarakat.

Sasaran dari pendayagunaan zakat adalah penduduk miskin yang mana Lembaga Amil Zakat Al-Ittihad membagi menurut tingkat keparahan kemiskinan menjadi fakir dan miskin. Dalam menentukan fakir miskin digunakan dua variabel, yaitu variabel ekonomi dan varibel non-ekonomi. Lembaga Amil Zakat Al-ittihad mendesain sasaran yang ingin dicapai dalam dua instrumen pokok yaitu : zakat (zakat fitrah dan zakat mal) yang dipergunakan untuk meningkatkan kesejahteraan fakir miskin dengan memberikan santunan hari raya dan santunan bulanan, serta infaq dan shodaqoh yang dipergunakan untuk penanggulangan kemiskinan, yang dalam hal ini diprioritaskan untuk biaya pendidikan anak yatim.

Salah satu faktor yang mengindikasikan ketaqwaan dari masyarakat desa Sidowungu adalah dibentuknya Lembaga Amil Zakat AlIttihad. Faktor lainnya yang mengindikasikan ketaqwaan adalah : (a) alasan muzakki membayar zakat karena sebagai bentuk ketaatan kepada ALLAH SWT, (b) zakat dibayarkan kepada fakir miskin melalui amil zakat maupun dibayarkan langsung ke fakir miskin, (c) warga yang mempunyai harta tidak sampai satu nishob juga giat bersedekah melalui infaq, sehingga dapat dikatakan tidak hanya mereka yang kaya saja yang menyisihkan hartanya, (d) membayar zakat dan menyisihkan harta dalam bentuk infaq dilakukan karena suatu keyakinan akan mendapatkan keberkahan. Para muzakki semakin termotifasi untuk terus membayar zakat serta mengeluarkan infaq dan shodaqoh karena merasakan dampak positif dalam kehidupannya 
berupa ketentraman hati, kemudahan rejeki dan keharmonisan rumah tangga.

\section{SARAN}

Bagi penelitian selanjutnya kami sarankan agar mengembangkan penelitian tentang peran zakat dalam penanggulangan kemiskinan dengan kombinasi potensi lokal dan kesalehan sosial sebagai variabel yang berbeda, sedangkan bagi Lembaga Amil Zakat Al-Ittihad disarankan untuk mengkaji kemungkinan program lain yang dapat dijalankan sebagai upaya menghentikan fenomena siklus kemiskinan di desa Sidowungu

\section{UCAPAN TERIMA KASIH}

Terima kasih kami sampaikan kepada Gubernur Jawa Timur dan Universitas Brawijaya yang telah memberi kesempatan untuk meyelesaikan penelitian ini. Terima kasih juga kepada masyarakat desa Sidowungu atas kesediannya menjadi tempat penelitian untuk mempelajari lembaga amil zakat tingkat desa dalam peranannya menanggulangi kemiskinan.

\section{DAFTAR PUSTAKA}

[1]. Astika, Ketut Sudhana. 2010. Budaya Kemiskinan di Masyarakat: Tinjauan Kondisi Kemiskinan dan Kesadaran Budaya Miskin di Masyarakat. Situs http://ojs.unud.ac.id/index.php/widya/artic le/download/3680/2708 diakses 09 januari 2014

[2]. Ala, Andre Bayo. 1981. Kemiskinan dan Strategi Memerangi Kemiskinan. Liberty Yogyakarta.

[3]. Anonim. 2012. Kecamatan Menganti Dalam Angka. Pemerintah Kabupaten Gresik Situs http:// Gresikkab.go.id. diakses: 11 Juli 2013

[4]. Moleong, Lexy J. 2013. Metodologi Penelitian Kualitatif. Remaja Rosdakarya Offset. Bandung.

[5]. Miles, Matthew B. dan Huberman, A. Michael. 1992. Analisis Data Kualitatif. Terjemah oleh Tjetjep Rohandi. UI-Pers. Jakarta.

[6]. Soenyono. 2007. Memahami Penelitian Kualitatif. Jenggala Pustaka Utama. Kediri.

[7]. Anonim. 2011. Undang-undang Republik Indonesia Nomor 13 Tahun 2011 Tentang
Penanganan Fakir Miskin. Situs http:// Kemsos.go.id. diakses: 27 Juni 2013

[8]. Assuyuthi,Imam Jalaludin. Al-jamius Shoghir Fil Ahadisil Basyirin Nadhir. Darul Fikr. Beirut.

[9]. Beik, Irfan Syuqi. 2009. Analisis Peran Zakat dalam Mengurangi Kemiskinan: Studi Kasus Dompet Duafa Republika. Situs http://imz.or.id. Diakses: 09 Mei 2013.

[10]. Anonim. 1999. Undang-undang Republik Indonesia Nomor 38 Tahun 1999 Tentang Pengelolaan Zakat. Situs http://kemenag.go.id diakses: 22 Maret 2013

[11]. Anonim. 2011. Undang-undang Republik Indonesia Nomor 23 Tahun 2011 Tentang Pengelolaan Zakat. Situs http://sumsel.kemenag.go.id diakses: 15 April 2014

[12]. Corak, Miles. 2006. Do Poor Children Become Poor Adults?, Lessons from a Cross Country Comparison of Generational Earnings Mobility. Iza Bonn Germany: Discussion paper No.1993. Situs http://ftp.iza.org/dp1993.pdf diakses 26 Oktober 2014

[13]. Hermawati, Istiana. 2013. Dampak Program Pengentasan Kemiskinan di kabupaten jayapura. Situs ournal.uny.ac.id/index.php/jpep/article/vie w/1110 diakses 17 Mei 2013

[14]. Chambers, Robert. 1987. Pembangunan Desa, Mulai Dari Belakang. LP3ES. Jakarta.

[15]. Geertz, Clifford. 1976. Involusi Pertanian, Proses perubahan Ekologi di Indonesia. BHRATARA K.A. Jakarta.

[16]. Ritzer, George., Goodman dan Douglas J. 2004. Teori Sosiologi Modern. Prenada Media. Jakarta.

[17]. Salim, Agus. 2008. Pengantar Sosiologi Mikro. Pustaka Pelajar. Yogyakarta.

[18]. Martono, Nanang. 2011. Sosiologi Perubahan Sosial: Perspektif Klasik, Modern, Posmodern, dan Poskolonial. Rajagrafindo Persada. Jakarta: 